Check for updates

The BMJ

kabbasi@bmi.com Follow Kamran on Twitter@KamranAbbasi Cite this as: BMJ 2021;373:n1360 http://dx.doi.org/10.1136/bmi.n1360 Published: 27 May 2021

\section{Declaring competing interests is a duty for doctors, scientists, and politicians}

\section{Kamran Abbasi executive editor}

Too many doctors, scientists, and politicians have something to hide. When the truth is revealed, it can come hard at you, although rarely as spectacularly as the claims about government incompetence made by Dominic Cummings. ${ }^{1}$ You might be hiding a payment from a drug or device manufacturer, an offer of shares or future employment, or something less tangible, such as a desire for political power or revenge, religious superiority, or professional success. The first step in tackling competing interests is transparency about what is tangible-in other words, the money.

When people line their pockets in matters of patients' and population health, the consequence is often that others pay by lining hospital beds and coffins. This is no lazy exaggeration or scare story: clinical and public health decisions distorted by financial conflicts do harm and do kill. Exhibit A: the pandemic response, from the UK to Japan.

Equally, conflicts of interest are a reality of working in public and private sectors. The requirement is not for purity but for transparency, as transparency is the bedrock for eliminating the influence of competing interests on decision making.

Transparency is not a panacea but is essential for health systems that are serious about putting patients first and minimising harm.

This is why The $B M J$ is a prime mover in attempts by an all party parliamentary committee to create a central register of interests for UK doctors, to mirror systems already in place in other countries. ${ }^{23}$ The General Medical Council is an obvious custodian of such a register, although both the GMC and the government seem reluctant to commit themselves. In this they are at odds with patients, the public, and, increasingly, the profession. ${ }^{4}$

When individuals and organisations fail to commit to transparency, the worry is that they do indeed have something to hide. Lack of transparency is a scandal that rots from the head, such as when a country's leaders refuse to hold an immediate inquiry into covid-19, ${ }^{5}$ try to suppress urgent public health data, ${ }^{6}$ persistently send mixed messages, ${ }^{7}$ and avoid collaboration with local bodies to tackle outbreaks. ${ }^{8}$

Similar scandals play out around the world, where the G20 countries pay lip service to vaccine equity while playing to the industry's agenda ${ }^{910}$; the transparency of national vaccine policy committees in the US and UK is inadequate and their advice misleading ${ }^{11}$; corporate decision making leads to around 400 ooo women being fitted with faulty implants ${ }^{12}$; data collected for health purposes are unavailable to patients but available for government or commercial use $\mathrm{e}^{1314}$; and contracts awarded in primary care lack scrutiny. ${ }^{15}$

Transparency of data, for instance, allows better understanding of the balance between a vaccine's safety and efficacy ${ }^{1617}$; why fewer non-covid hospital admissions were accompanied by more non-covid deaths ${ }^{18}$; when to implement and ease lockdowns ${ }^{19}$; which pandemic innovations to retain ${ }^{20}$; and how the pandemic affects women's wellbeing and the provision of mental health services in primary care. $^{2122}$

None of us should feel aggrieved at declaring competing interests as part of a clinical, scientific, or political role. It is our duty to patients and the public. The GMC must accept its responsibility to implement a central mandatory register of interests for the UK's doctors, the key decision makers for a patient's health. The government must extend that logic to population health by ensuring full transparency in the competing interests of policy makers, scientists, and politicians. Transparency is not a panacea, but fighting or delaying it-as Boris Johnson is doing with a covid-19 public inquiry-suggests something to hide and is as good as saying "mea culpa."

lacobucci G. Covid-19: Thousands died needlessly from UK pandemic response, says PM's former aide. $B M$ 2021;373:n1374doi: 10.1136/bmj.n1374.

2 Coombes R. Doctors' duty to declare their interests should be enforced, says GMC. BM/2021;373:n1329. doi: 10.1136/bmj.n1329 pmid: 34031033

Rimmer A. Briefing: Why do we need a mandatory register of doctors' interests?BM/2021;373:n1280. doi: 10.1136/bmj.n1280 pmid: 34016582

4 Mahase E. RCGP calls on GMC to introduce mandatory and public declaration of interests register. BMJ 2019;367:16695 doi: 10.1136/bmj.l6695 pmid: 31771954

5 McKee M. What went wrong in the UK's covid-19 response?BMJ 2021;373:n1309. doi: 10.1136/bmj.n1309 pmid: 34031098

6 lacobucci G. Covid-19: Single vaccine dose is 33\% effective against variant from India, data show. BMJ2021;373:n1346.

doi: 10.1136/bmj.n1346 pmid: 34035039

7 lacobucci G. Sixty seconds on ... mixed messages. BMJ2021;373:n1318 doi: 10.1136/bmj.n1318 pmid: 34021005

8 lacobucci G. Covid-19: Are high rates of B.1.617.2 linked to vaccine hesitancy?BM/2021;373:n1345. doi: 10.1136/bmj.n1345 pmid: 34035010

9 Mahase E. Covid-19: Rich countries are putting "relationships with big pharma” ahead of ending pandemic, says Oxfam. BMJ2021;373:n1342. doi: 10.1136/bmj.n1342 pmid: 34035051

10 Buse K, Pillay Y. The 2021 Rome Global Health Summit: a missed opportunity. BMJ Opinion. 25 May 2021. https://blogs.bmj.com/bmj/2021/05/25/the-2021-rome-global-healthsummit-a-missed-opportunity.

11 Thacker PD. Covid-19: How independent were the US and British vaccine advisory committees?BMJ 2021;373:n1283doi: 10.1136/bmj.n1283.

12 Dyer C. Women harmed by faulty breast implants should be compensated, says French court. BMJ2021;373:n1307. doi: 10.1136/bmi.n1307 pmid: 34016643

13 Salisbury H. Helen Salisbury: Should patients worry about their data?BMJ 2021;373:n1325. doi: 10.1136/bmj.n1325 pmid: 34035007

14 Richards T, Scowcroft H, Doble E, Price A, Abbasi K. Healthcare decision making should be democratised. BMJ2021;373:n1225. doi: 10.1136/bmj.n1225 pmid: 34011490 
15 Limb M. UK campaigners mount legal challenge over US takeover of GP surgeries. BMJ 2021;373:n1321. doi: 10.1136/bmj.n1321 pmid: 34020963

16 Pottegård A, Lund LC, Karlstad Ø, etal. Arterial events, venous thromboembolism, thrombocytopenia, and bleeding after vaccination with Oxford-AstraZeneca ChAdOx1-S in Denmark and Norway: population based cohort study. BMJ2021;373:n1114 doi: 10.1136/bmj.n1114 pmid: 33952445

17 Perera R, Fletcher J. Thromboembolism and the Oxford-AstraZeneca vaccine. BM/2021:373:n1159. doi: 10.1136/bmj.n1159 pmid: 33952506

18 Bodilsen J, Nielsen PB, Søgaard M, etal. Hospital admission and mortality rates for non-covid diseases in Denmark during covid-19 pandemic: nationwide population based cohort study. BM 2021;373:n1135. doi: 10.1136/bmj.n1135 pmid: 34035000

19 Hunter PR. Will the Indian variant B.1.617.2 delay England's lockdown roadmap? BMJ Opinion 18 May 2021. https://blogs.bmj.com/bmi/2021/05/18/will-the-indian-variant-b-1-617-2-delayenglands-lockdown-roadmap.

20 Oliver D. David Oliver: The pandemic has delivered clinical service innovations worth keeping BMJ 2021;373:n1306doi: 10.1136/bmi.n1306 .

21 Gerada C. Clare Gerada: Closing the gender wellbeing gap in medicine. BMJ2021;373:n1312. doi: 10.1136/bmj.n1312 pmid: 34035054

22 Mughal F, Hossain MZ, Brady A, Samuel J, Chew-Graham CA. Mental health support through primary care during and after covid-19. BMJ2021;373:n1064

doi: 10.1136/bmi.n1064 pmid: 33947703 